\title{
Effect of Different Processing Methods on Anti-Nutrients Content and Protein Quality of Improved Lupin (Lupinus Albus L.) Cultivar Seeds
}

\author{
Mohamed Ahmed M. Omer ${ }^{1}$, ElShazali Ahmed Mohamed ${ }^{2}$, Isam A. Mohamed Ahmed ${ }^{1,3}$ \\ Abu EIGasim A. Yagoub ${ }^{4}$, Elfadil E. Babiker ${ }^{5 *}$
}

${ }^{I}$ Department of Food Science and Technology, Faculty of Agriculture, University of Khartoum, Khartoum, Sudan

${ }^{2}$ Elfeij Technical College, postal code 3542, Wad Medani, Sudan

${ }^{3}$ Arid Land Research Center, Tottori University, 1390 Hamasaka, Tottori 680-0001, Japan

${ }^{4}$ Faculty of Agriculture, University of Zalingie, P.O. Box 6, Zalingie, Sudan

${ }^{5}$ Department of Food Science and Nutrition, College of Food and Agricultural Sciences, King Saud University, P. O. Box 2460, Riyadh 11451, Kingdom of Saudi Arabia

\section{A R T I C L E I N F O}

\section{Article history:}

Received 09 April 2015

Accepted 01 December 2015

Available online, ISSN: 2148-127X

\section{Keywords.}

Boiling

Chemical composition

Fermentation

Germination

In vitro protein digestibility

Lupin

Protein fractions

\author{
A B S T R A C T
}

Lupin seeds of genetically improved cultivar (Golo) were subjected to different processing methods and investigated according to anti-nutritional factors content and protein quality. Results showed that tannin content of raw seeds was significantly increased in sprouted and debittered seeds before and after boiling but in fermented seeds it declined significantly. Phytate content was significantly decreased in all processed seeds with a significant reduction observed in germinated seeds. The reduction in Phytate as a result of processing was accompanied by a significant improvement in protein digestibility. The protein content of lupin seeds decreased in sprouted seeds and increased in fermented and debittered ones. Boiling of the seeds even the sprouted ones significantly increased the protein content compared to raw lupin seeds. In raw lupin seeds, globulins comprised the major fraction followed by glutelin. Debittered seeds characterized by high glutelin, fermented are characterized by high globulin while germinated characterized by both fractions. Most of the amino acids level was increased after processing of the seeds.

${ }^{*}$ Corresponding Author:

E-mail: ebabiker.c@ksu.edu.sa

\section{Introduction}

Interest in lupin production is increasing due to its potential as a source of protein, pharmaceutical purposes, green manure and as a natural component of plant pesticides due to the high alkaloid content (James et al., 2004; Lampart-Szczapa et al., 2003). Lupin is a legume rich in protein, essential amino acids, dietary lipids, fiber, minerals and vitamins (KohaJdoVá et al., 2011). Lupin is considered as an excellent source of protein for both human and animal nutrition (Martınez-Villaluenga et al., 2007) that could be used instead of soybean in countries that do not produce soybean. Lupin seed protein is an excellent source of lysine but poor in the sulfurcontaining amino acids (El-Adawy et al., 2001). According to Osborne fractionation, lupin proteins can be divided into water-soluble albumins, salt-soluble globulins, alcohol-soluble prolamins and acid/alkalisoluble glutelins (Mandal and Mandal, 2000). Globulins are the major storage proteins of lupin seeds while prolamines and glutelins are detected in small amounts (Mandal and Mandal, 2000). The production of flatulence from the $\alpha$-galactoside oligosaccharides, and the presence of antinutrients, such as tannins are the major reasons that preclude a greater inclusion of lupin and cowpea in human or animal diets (Ibrahim et al., 2002). Processing methods, such as soaking, germination, fermentation, boiling and addition of enzymes has been reported by many researchers to reduce the amount of antinutritional factors and to improve the nutritional value of cereals and legume seeds (Frías et al., 2000; Idris et al. 2007; Mohiedeen et al., 2010, Mohamed Nour et al., 2010; Osman et al., 2010; Sokrab et al., 2012). Germination of seed legumes is practiced in many countries and reported to be associated with improvements in the nutritive value of seeds and their quality (Mohamed Nour et al., 2010; Sokrab et al., 2012). It has also been reported that germination and fermentation are effective methods of reducing polyphenols, phytic acid and thereby increasing the protein digestibility and improving sensory properties. On the other hand, fermentation is a common practice in African and Southeast Asian countries, is believed to enhance the nutritional quality of foods in addition to increasing shelf life. Breakdown of food components by 
microbial enzymes may explain the enrichment for such properties during fermentation (Kim et al., 2004; Wong and Mine, 2004). Fermentation, however, offers potential for extensive applications, particularly with respect to the preservation of legumes, cereals, and root crops and the provision of safe foods for developing countries (Deshpande et al., 2000). In Sudan, lupin seeds are processed in several ways including boiling in water in the presence or absence of table salt, germination followed by boiling or fermentation for a short period of time ( 2 days) followed by boiling. The main aim of this study was to evaluate the effect of different processing methods on antinutrients contents and protein quality of lupin seeds.

\section{Materials and Methods}

\section{Materials}

Lupin seeds (Lupinus albus L.) of cultivar Golo (white lupin) which was improved by conventional breeding were obtained from Crop Research Station, Shambat, Sudan. The seeds were carefully cleaned and freed from foreign materials and stored in polyethylene bags at $4^{\circ} \mathrm{C}$. Chemicals used in the present study were of reagent grade.

\section{Processing Methods}

Home debittering process: The lupin seeds were steeped overnight in water containing $0.5 \% \mathrm{NaCl}$. Then, soaking water was decanted, and the seeds were boiled in fresh water until the color changed from white to light yellow (3-5 h). Boiling of the seeds was repeated, and the seeds were steeped twice as above mentioned. Then the boiled and untreated (control) seeds were freeze-dried (Viritis Unitop 600SL, New York), milled (KENWOOD Model CG510, China) to pass a $0.25 \mathrm{~mm}$ sieve and kept in polyethylene bags at $4{ }^{\circ} \mathrm{C}$ for further analysis.

Germination process: Germination was carried out in an incubator at $20^{\circ} \mathrm{C}$ for 6 days according to Mohamed Nour et al. (2010). Samples were periodically taken at 2, 4 and 6 days intervals. Part of the sprouted seeds was boiled in water for 30 minutes. Both raw and boiled samples were freeze-dried, milled to pass a $0.25 \mathrm{~mm}$ sieve and kept in polyethylene bags at $4^{\circ} \mathrm{C}$ for further analysis.

Fermentation process: About 100 grams of lupin seeds were washed and suspended in sterile distilled water (333 mL) using a $500 \mathrm{~mL}$ Erlenmeyer flask protected from the daylight with aluminum foil. The suspension was left to ferment naturally in an orbital shaker incubator (Unitrin, Infors AG, Switzerland) at $220 \mathrm{rpm}$ for 2 days at $37{ }^{\circ} \mathrm{C}$. Part of the fermented seeds was boiled in water for 30 minutes. Then both raw and boiled fermented seeds were freeze-dried and milled and then stored at $4{ }^{\circ} \mathrm{C}$ for further analysis.

\section{Analytical Methods}

Tannin determination: The modified vanillin- $\mathrm{HCl}$ method was used for tannin determination as described by Price et al. (1978). A $200 \mathrm{mg}$ sample was extracted with $10 \mathrm{~mL}$ of $1 \% \mathrm{HCl}$ in methanol (v/v) for $20 \mathrm{~min}$ in capped rotating test tubes. Then, $5 \mathrm{~mL}$ of $0.5 \%$ Vanillin reagent was added to $1 \mathrm{~mL}$ of the extract. Thereafter, the mixture was incubated at $30^{\circ} \mathrm{C}$ for $20 \mathrm{~min}$ and then the absorbance was read at $500 \mathrm{~nm}$. A standard curve was prepared to express the results as catechin equivalents, i.e., amount of catechin (mg per $\mathrm{mL}$ ) that gives a color intensity equal to that given by tannins after correcting for blank.

Phytate determination: The phytic acid content was determined as described by Wheeler and Ferrel (1971) using $2.0 \mathrm{~g}$ of dried sample. A standard curve of various concentrations of $\mathrm{Fe}\left(\mathrm{NO}_{3}\right)_{2}$ was plotted to calculate the ferric ion concentration. The phytate phosphorus was calculated from the standard curve assuming 4:6 iron to phosphorus molar ratio.

In vitro protein digestibility determination: The in vitro digestibility of the protein was determined as described by Monjula and John (1991). Triplicate samples with a known weight containing $16 \mathrm{mg}$ nitrogen were digested with pepsin $(1 \mathrm{mg})$ in $15 \mathrm{~mL}$ of $0.1 \mathrm{M} \mathrm{HCl}$ at 37 ${ }^{\circ} \mathrm{C}$ for $3 \mathrm{~h}$. The reaction was terminated by the addition of $15 \mathrm{~mL}$ of $10 \%$ trichloroacetic acid (TCA). Then, the mixture was filtered through Whatman No. 1 filter paper. The TCA soluble fraction was assayed for nitrogen using the micro-Kjeldahl's method. Digestibility was calculated by using the following equation:

$$
\mathrm{PD}(\%)=\frac{\mathrm{N} \text { in supernatant }-\mathrm{N} \text { in blank }}{\mathrm{N} \text { in sample }} \times 100
$$

\section{PD: Protein digestibility}

Determination of protein content and fractionation: The protein content was determined according to AOAC method (1990). For protein fractionation, the stepwise extraction of nitrogen using various solvents was applied according to the method of Landry and Moureaux (1970). Firstly, the salt-soluble globulin was obtained by adding $0.5 \mathrm{M} \mathrm{NaCl}$ to the sample, and the mixture was then stirred three times for $0.5,1$, and $30 \mathrm{~min}$ at $4^{\circ} \mathrm{C}$. Secondly, the water-soluble albumin was obtained by twice extraction of the residue with an equal volume of distilled water for $15 \mathrm{~min}$ at $4^{\circ} \mathrm{C}$. Thirdly, the alcoholsoluble prolamin was obtained by twice extraction of the residue with $60 \%$ ethanol for $30 \mathrm{~min}$ at $20^{\circ} \mathrm{C}$ and then at $60^{\circ} \mathrm{C}$ for $30 \mathrm{~min}$, followed by extraction with $55 \%$ isopropanol $(\mathrm{Pr}-\mathrm{OH})$ at $20^{\circ} \mathrm{C}$. Fourthly, G1-glutelin was extracted from the residue using $60 \%$ ethanol plus $0.6 \%$ of 2-mercaptoethanol (2-ME) and stirred twice for $30 \mathrm{~min}$ $\left(20^{\circ} \mathrm{C}\right)$, then extracted with $55 \%$ Pr-OH containing $2-\mathrm{ME}$ $(0.6 \%)$ at $20^{\circ} \mathrm{C}$ (twice) for $30 \mathrm{~min}$. Lastly, G2- and G3glutelins were achieved following treatment of the remaining residue with $0.6 \% 2-\mathrm{ME}$ and $0.5 \mathrm{M} \mathrm{NaCl}$ in $0.0125 \mathrm{M}$ borate buffer ( $\mathrm{pH} 10$ ), and with $0.6 \%$ 2-ME and $0.5 \mathrm{M}$ sodium dodecyl sulfate (SDS) in $0.0125 \mathrm{M}$ borate buffer ( $\mathrm{pH} 10)$, respectively. The nitrogen of each of these fractions was determined by the micro-Kjeldahl method.

Amino acids composition: The amino acids composition was estimated according to the standard methods using high-performance liquid chromatography (HPLC) (Sykam system Model S7130, Sykam GmbH, 
Eresing, Germany). About $200 \mathrm{mg}$ of the sample was taken in a hydrolysis tube, and $5 \mathrm{ml}$ of $6 \mathrm{~N} \mathrm{HCl}$ was added. The tube was tightly closed and incubated at $110^{\circ} \mathrm{C}$ for $24 \mathrm{~h}$. After incubation the solution was filtered, and $200 \mathrm{ml}$ of the filtrate was evaporated at $140^{\circ} \mathrm{C}$ for $1 \mathrm{~h}$. The hydrolysate after drying was diluted with $1.0 \mathrm{ml}$ of $0.12 \mathrm{~N}$ citrate buffer ( $\mathrm{pH} 2.2)$. Aliquot $(150 \mu \mathrm{l})$ of the sample hydrolysates was injected into an action separation column at $130^{\circ} \mathrm{C}$. Elution buffers (solvent A, pH 3.45 and solvent $\mathrm{B}, \mathrm{pH} 10.85$ ) and ninhydrin solution were simultaneously delivered to a high-temperature reactor coil $(16 \mathrm{~m})$ at $0.7 \mathrm{ml} / \mathrm{min}$ flow rate. The buffer/ninhydrin mixture was heated in the reactor at $130^{\circ} \mathrm{C}$ for $2 \mathrm{~min}$, and then the formed products were detected at wavelengths of 570 and $440 \mathrm{~nm}$ on a dual channel photometer. The amino acids composition was calculated from the area under the curve of the standards and expressed as mg/100gm. The sulphur-containing amino acids were oxidized using performic acid before the acid hydrolysis.

\section{Statistical Analysis}

Each determination was carried out on three separate samples and then triplicates samples were analyzed and figures were then averaged. Data were measured by the analysis of variance (ANOVA) (Snedecor and Cochran, 1987) while mean values were compared by Duncan's test $(\mathrm{P} \leq 0.05)$.

\section{Results and Discussion}

Effect of Processing Methods on Antinutrients and Protein Digestibility of Lupin Seeds

Figures 1 and 2 show the effect of different processing methods on anti-nutritional factors and in vitro protein digestibility (IVPD) of lupin seeds, respectively. Tannin content of raw lupin seeds was $100.02 \mathrm{mg} / 100 \mathrm{gm}$. Boiling of lupin seeds significantly $(\mathrm{P} \leq 0.05)$ increased tannin content. Germination of the seeds alone significantly $(\mathrm{P} \leq 0.05)$ increased tannin content, and further significant increment in tannin was observed when germination was accompanied by boiling process, with a maximum value $(134.56 \mathrm{mg} / 100 \mathrm{~g})$ obtained for 6 days germinated and boiled seeds. This could be a result of solubilization of tannin when the seeds were soaked in water and migration of tannin to the outer layer as a result of germination, as indicated by the browning of the germinated seeds (Ahmed et al., 1996). However, fermentation alone and when accompanied by boiling significantly $(\mathrm{P} \leq 0.05)$ decreased the level of tannin of lupin seeds. The reduction in the degree of tannin during fermentation may be attributed to the action of the enzyme tannase released during fermentation. Moreover, boiling significantly $(\mathrm{P} \leq 0.05)$ increased tannin content of fermented seeds but still lower than that of lupin seeds tannin. Debittering significantly $(\mathrm{P} \leq 0.05)$ increased the level of tannin of lupin seeds. This could be due to the fact that boiling of the seeds in the presence of salt may solubilize the tannin of the seeds as well as the migration of the soluble tannin to the inner layers of the seeds. The phytate content of lupin seeds was $280.53 \mathrm{mg} / 100 \mathrm{~g}$. The seeds are rich in protein $(38.52 \%)$. Therefore, they had high phytate levels. It has been reported that in legumes, phytates are associated with protein bodies (Sulieman et al., 2007) and therefore, phytate levels should increase with increasing protein content. All processing methods significantly reduced $(\mathrm{P} \leq 0.05)$ phytate content of lupin seeds and further reduction was observed when the process was accompanied by boiling. Ordinary boiling of lupin seeds brought about a significant decrease in phytic acid content when compared to raw. The loss of phytic acid during boiling could probably be explained on the basis that phytase activity at a temperature of $40-55^{\circ} \mathrm{C}$ may degrade inositol hexaphosphate to the pentaphosphate or lower molecular weight forms (ElMaki et al., 2007). Further, they observed that phytic acid content decreased while boiling because insoluble complexes between phytate and other components were formed and, accordingly, the amount of free phytate was reduced (ElMaki et al., 2007). The loss in phytate during debittering might be due to discharge of phytate ions into the soaking water under the effect of a concentration gradient, which governs the rate of diffusion. Moreover, low level of phytate in germinated and fermented seeds is likely due to the action of the enzyme phytase on phytate. Yorgancilar and Bilgiçli (2014) reported that bulgur processing of bitter and sweet lupin seeds (Lupinus albus L.) caused a significant reduction $(\mathrm{P} \leq 0.05)$ in phytic acid content. The IVPD of lupin seeds was $68.26 \%$. Boiling of lupin seeds significantly $(\mathrm{P} \leq 0.05)$ increased the IVPD of the seeds (Fig. 2). Each of sprouting, fermentation and debittering significantly $(\mathrm{P} \leq 0.05)$ improved the IVPD of the seeds and further improvement in IVPD was observed after boiling of sprouted, fermented and debittered seeds. Boiling of the seeds had been reported to reduce the IVPD but when preceded by germination or fermentation the effect of boiling was alleviated. Germination, among other technological processes, has been widely used for its ability to decrease the level of antinutritional factors existing in legume seeds in the meanwhile improving the concentration and bioavailability of their nutrients (Urbano et al., 2005). The comprehensive degradation of seed storage proteins that occurs during this process improves the protein digestibility and the essential amino acid content, consequently enhancing the nutritional value of legumes (Kuo et al., 2004). It has been reported that fermentation and boiling of Sicklepod-fermented flour significantly $(\mathrm{P} \leq 0.05)$ increased the protein digestibility compared to that of the raw sample (Osman et al., 2010). However, contradictory results showed that the protein digestibility of fermented Uji flour (Onyango et al., 2004) and maize (Yousif and El Tinay, 2000) was decreased after boiling. The decline in IVPD after boiling was possible because of the formation of protein-antinutrient complexes which are resistant to pepsin attack as explained by Onyango et al. (2004) or may be as a result of the formation of cross-linkages within and between protein chains such as lysinoalanine and lanthionine, and partly because of the loss of certain attacking sites of the digestive enzyme and thus affected the protein quality. 
However, in the present study the improvement in IVPD of sprouted, fermented or debittered lupin seeds before and after boiling may be attributed not only to the removal/reduction of antinutrients (Idris et al., 2007; Mohiedeen et al., 2010, Mohamed Nour et al., 2010; Osman et al., 2010; Sokrab et al., 2012), but also to the structural disintegration of the native protein, including enzyme inhibitors and lectins, phytase activity to break down phytic acid (Sulieman et al., 2007) in the seeds. Moreover, the study revealed that the phytate had a stronger impact on IVPD than tannin as indicated by the direct relation between tannins and IVPD (as the tannins increases, the rate of digestion increases) and reverse relation between phytate and IVPD.

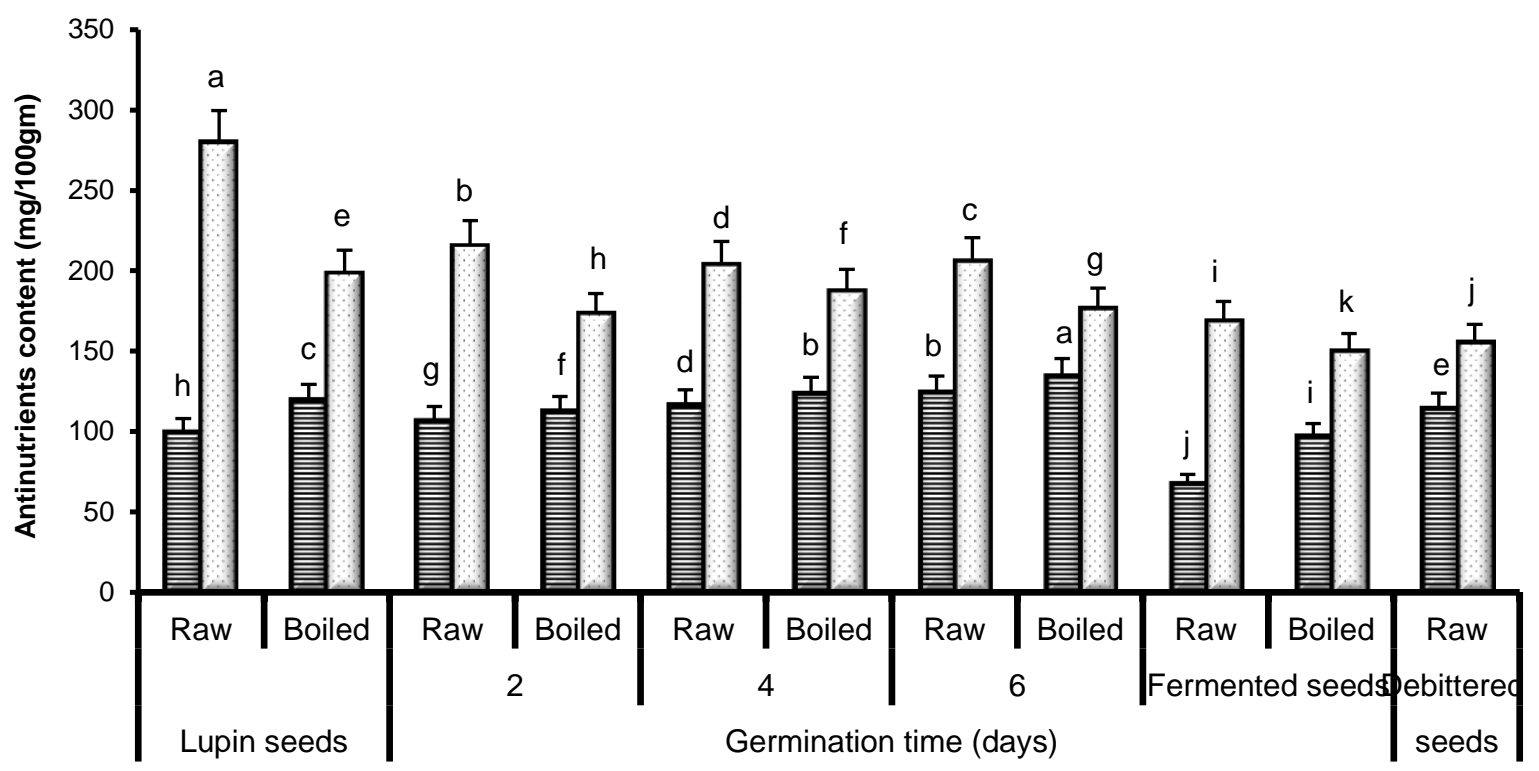

Figure 1 Changes in tannins (lined bars) and phytate (dotted bars) during processing of lupin seeds. For each parameter bars not sharing a common superscript letter are significantly different at $\mathrm{P} \leq 0.05$.

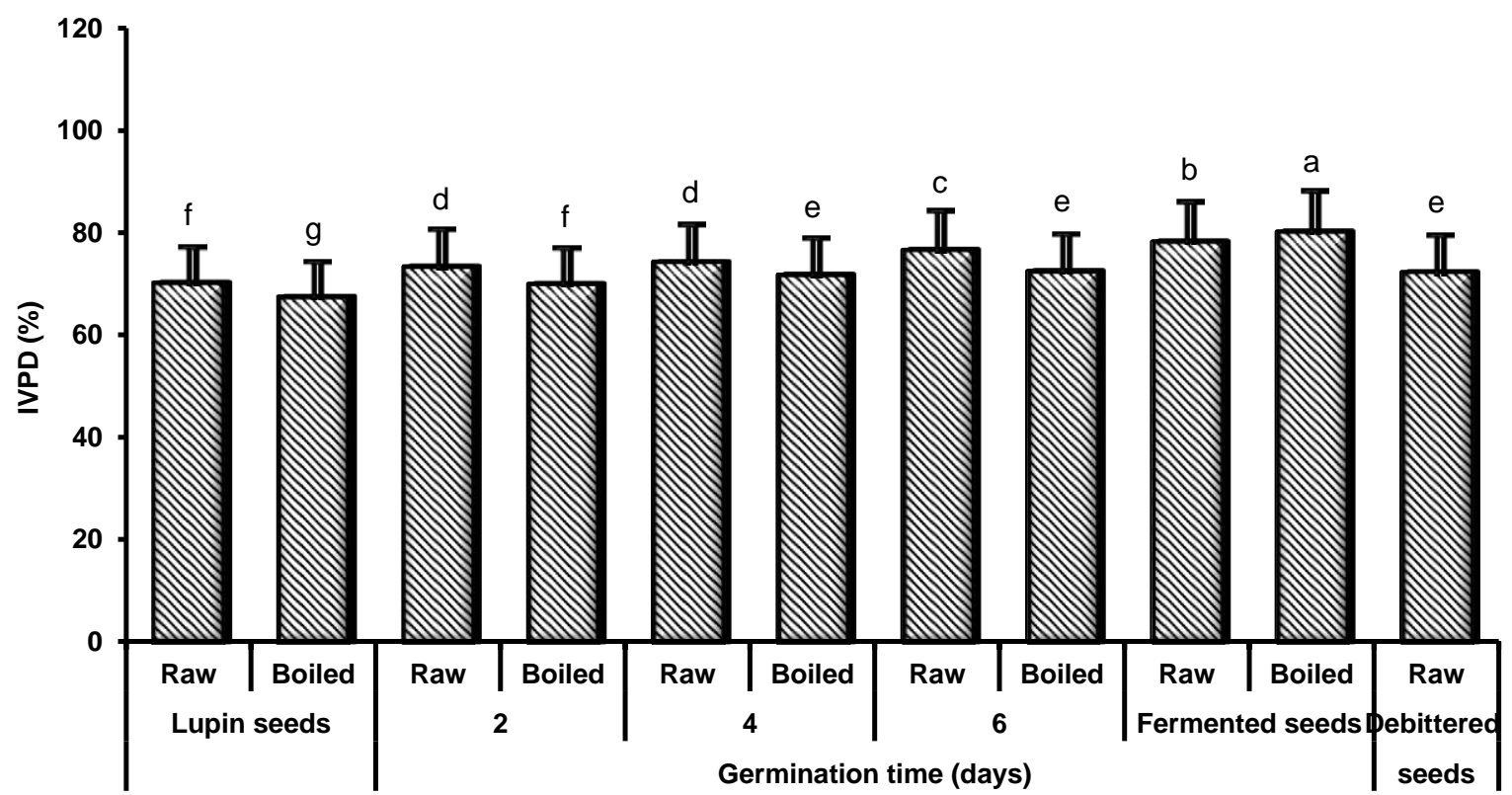

Figure 2 Changes in in vitro protein digestibility (IVPD) during processing of lupin seeds. Bars not sharing a common superscript letter are significantly different at $\mathrm{P} \leq 0.05$ 
Effect of Processing Methods on Protein Content and Fractions of Lupin Seeds

Table 1 shows the effect of different processing methods on protein content and Osborne fractions of raw and processed lupin seeds. The protein content $(38.52 \%)$ of lupin cultivar examined was the major nutrient exceeding the values obtained for carbohydrates (37.62\%). The results obtained confirm that lupin seeds are protein-rich and agree with the data reported by many researchers for different lupin seeds (Fernandez and Batterham, 1995; Martınez-Villaluenga et al., 2007). Boiling of lupin seeds significantly $(\mathrm{P} \leq 0.05)$ increased the protein to $42.12 \%$, but germination alone slightly decreased the protein content of the seeds. However, boiling of germinated seeds significantly $(\mathrm{P} \leq 0.05)$ increased the protein content. Fermentation before and after boiling and debittering process significantly $(\mathrm{P} \leq 0.05)$ increased the protein content of lupin seeds. The increment in protein content after boiling of germinated and fermented seeds could be attributed to solubilization and concentration of the protein. Moreover, the extensive breakdown of seed-storage proteins that takes place during this process enhanced the nutritional value of legumes (Kuo et al., 2004). The predominant fraction of lupin seed before and after boiling was globulins, which was $45 \%$ and $57.24 \%$, respectively of the total protein followed by albumin, prolamin, glutelin and the insoluble protein fractions. Boiling of lupin seeds significantly $(\mathrm{P} \leq 0.05)$ increased all protein fractions due to an increase in protein content of the seeds. Most of the data in the literature coincide with high values for the globulin fraction in legume seeds (Duranti et al., 1990; Gulewicz et al., 2008). Each of germination and fermentation before and after boiling significantly $(\mathrm{P} \leq 0.05)$ reduced the nitrogen content of albumin fraction. The reduction in the nitrogen content of albumin, with significant amounts, continued during the germination period prolonged, reaching a minimum value of $11.14 \%$ at the end of germination period and further reduction was observed after boiling $(9.35 \%)$. The reduction in albumin is likely to be due to the fact that albumin is a water soluble protein and may be extracted in soaking water prior and after germination and fermentation. A decrease in the content of albumin and globulin fractions after germination was reported by Gulewicz et al. (2008) in some lupin cultivars. Debittering of the seeds significantly $(\mathrm{P} \leq 0.05)$ decreased the level of all fractions except glutelin that was significant $(\mathrm{P} \leq 0.05)$ increased to $34.94 \%$ compared to that of raw lupin seeds (15.50\%). Fermentation alone resulted in a slight rise in the level of prolamin $(5.74 \%)$ but decreased significantly $(\mathrm{P} \leq 0.05)$ to $2.88 \%$ after boiling. Glutelin content was significantly $(\mathrm{P} \leq 0.05)$ increased for all processing methods with higher value observed after boiling of raw seeds (51.90\%). Insoluble protein fraction was significantly $(\mathrm{P} \leq 0.05)$ increased after germination and natural sweetening but significantly $(\mathrm{P} \leq 0.05)$ decreased after fermentation. However, boiling of fermented seeds significantly $(\mathrm{P} \leq 0.05)$ increased the level of insoluble protein. This variation in insoluble protein between processing methods is likely to be attributed to the fact that during fermentation the enzymes of the fermenting media may act on the protein fraction and lower its level. Mohiedeen et al. (2010) proved the effect of heat treatment on the solubility of the protein fractions. The observed variations in the globulin fractions after germination, fermentation, and boiling are the consequences of the changes in the molecular mass of different proteins. The dissociation, denaturation or hydrolysis of the proteins may modify their solubility, therefore; they are extracted in other conditions (Yagoub et al., 2004). Chilomer et al. (2010) reported an increase in the residual protein fraction after germination of lupin seeds.

Table 1 Effect of different processing methods on protein content and fractions (\%) of lupin seeds.

\begin{tabular}{|c|c|c|c|c|c|c|c|c|c|c|c|}
\hline \multirow{3}{*}{$\begin{array}{l}\text { Protein/ } \\
\text { fraction }\end{array}$} & \multirow{2}{*}{\multicolumn{2}{|c|}{ Lupin seeds }} & \multicolumn{6}{|c|}{ Germination time (days) } & \multirow{2}{*}{\multicolumn{2}{|c|}{$\begin{array}{c}\text { Fermented } \\
\text { seeds }\end{array}$}} & \multirow{3}{*}{$\begin{array}{c}\text { Home } \\
\text { debittering }\end{array}$} \\
\hline & & & \multicolumn{2}{|c|}{2} & \multicolumn{2}{|c|}{4} & \multicolumn{2}{|c|}{6} & & & \\
\hline & Raw & Boiled & Raw & Boiled & Raw & Boiled & Raw & Boiled & Raw & Boiled & \\
\hline & 38.52 & 42.12 & 36.51 & 40.42 & 37.96 & 41.65 & 38.19 & 43.37 & 41.02 & 49.08 & 41.07 \\
\hline Protein & $\pm 0.97^{\mathrm{d}}$ & $\pm 0.85^{\mathrm{c}}$ & $\pm 0.57^{\mathrm{e}}$ & $\pm 0.21^{\mathrm{c}}$ & $\pm 0.54^{\mathrm{f}}$ & $\pm 1.61^{\mathrm{c}}$ & $\pm 0.99^{\mathrm{d}}$ & $\pm 0.94^{\mathrm{b}}$ & $\pm 0.94^{\mathrm{c}}$ & $\pm 0.95^{\mathrm{a}}$ & $\pm 0.48^{\mathrm{c}}$ \\
\hline & 17.55 & 14.26 & 17.23 & 15.27 & 13.83 & 12.63 & 11.14 & 9.35 & 12.77 & 10.58 & 9.54 \\
\hline A & $\pm 0.13^{\mathrm{a}}$ & $\pm 0.23^{\mathrm{b}}$ & $\pm 0.10^{\mathrm{a}}$ & $\pm 0.09^{\mathrm{b}}$ & $\pm 0.12^{\mathrm{c}}$ & $\pm 0.26^{\mathrm{d}}$ & $\pm 0.12^{\mathrm{e}}$ & $\pm 0.09^{\mathrm{f}}$ & $\pm 0.23^{\mathrm{d}}$ & $\pm 0.07^{\mathrm{e}}$ & $\pm 0.31^{\mathrm{f}}$ \\
\hline & 45.00 & 57.24 & 27.70 & 39.34 & 26.55 & 34.80 & 24.77 & 32.61 & 38.72 & 26.54 & 24.25 \\
\hline Gle & $\pm 0.47^{\mathrm{b}}$ & $\pm 0.17^{\mathrm{a}}$ & $\pm 0.13^{\mathrm{e}}$ & $\pm 0.12^{\mathrm{c}}$ & $\pm 0.10^{\mathrm{f}}$ & $\pm 0.18^{\mathrm{d}}$ & $\pm 0.05^{\mathrm{g}}$ & $\pm 0.16^{\mathrm{e}}$ & $\pm 0.16^{\mathrm{c}}$ & $\pm 0.13^{f}$ & $\pm 0.18^{\mathrm{g}}$ \\
\hline & 5.00 & 5.86 & 6.15 & 6.25 & 4.83 & 5.92 & 4.09 & 8.48 & 5.74 & 2.88 & 4.61 \\
\hline Pro & $\pm 0.10^{\mathrm{c}}$ & $\pm 0.10^{\mathrm{b}}$ & $\pm 0.31^{\mathrm{b}}$ & $\pm 0.16^{\mathrm{b}}$ & $\pm 0.13^{\mathrm{d}}$ & $\pm 0.09^{\mathrm{b}}$ & $\pm 0.19^{\mathrm{d}}$ & $\pm 0.14^{\mathrm{a}}$ & $\pm 0.10^{\mathrm{c}}$ & $\pm 0.16^{\mathrm{e}}$ & $\pm 0.28^{\mathrm{d}}$ \\
\hline & 15.50 & 9.50 & 25.85 & 19.67 & 32.83 & 24.16 & 36.36 & 30.70 & 27.66 & 35.00 & 34.94 \\
\hline Glutelin & $\pm 0.20^{\mathrm{h}}$ & $\pm 0.37^{\mathrm{i}}$ & $\pm 0.15^{\mathrm{f}}$ & $\pm 0.23^{\mathrm{g}}$ & $\pm 0.07^{\mathrm{c}}$ & $\pm 0.11^{\mathrm{f}}$ & $\pm 0.14^{\mathrm{a}}$ & $\pm 0.09^{\mathrm{d}}$ & $\pm 0.11^{\mathrm{e}}$ & $\pm 0.09^{\mathrm{b}}$ & $\pm 0.14^{\mathrm{b}}$ \\
\hline Insoluble & 18.75 & 14.25 & 20.92 & 20.13 & 22.69 & 21.56 & 23.18 & 19.30 & 15.96 & 24.42 & 25.75 \\
\hline & $\pm 0.09^{\mathrm{e}}$ & $\pm 0.09^{\mathrm{g}}$ & $\pm 0.07^{\mathrm{e}}$ & $\pm 0.06^{\mathrm{e}}$ & $\pm 0.13^{\mathrm{d}}$ & $\pm 0.35^{\mathrm{d}}$ & $\pm 0.26^{\mathrm{c}}$ & $\pm 0.17^{\mathrm{f}}$ & $\pm 0.22^{\mathrm{f}}$ & $\pm 0.08^{\mathrm{b}}$ & $\pm 0.22^{\mathrm{a}}$ \\
\hline Recovery & 101.80 & 101.11 & 97.84 & 100.66 & 100.72 & 98.62 & 99.55 & 100.43 & 100.85 & 99.42 & 99.08 \\
\hline
\end{tabular}

Values are means $\pm \mathrm{SD}, \mathrm{n}=3$. Within a row, means not sharing a common superscript letter are significantly different at $\mathrm{P} \leq 0.05$ 
Effect of Processing Methods on Amino Acids Contents of Lupin Seeds

Table 2 shows the amino acids composition of raw and processed lupin seeds. Glutamic acid, arginine, leucine and aspartic acid are the major amino acids in lupin seed with values of 4.64, 2.99, 2.15 and 2.08 $\mathrm{mg} / 100 \mathrm{gm}$ protein, respectively. Relative to the FAO reference protein pattern (FAO/WHO, 1991), methionine was the limiting amino acid. Lupin seed was found to have low sulfur-containing amino acids as reported by Martinez-Villaluenga et al. (2007) and Guewicz et al. (2008). Lysine content of the seed was $1.14 \mathrm{mg} / 100 \mathrm{gm}$ protein, which is significantly $(\mathrm{P} \leq 0.05)$ lower than that of the FAO reference protein. Lone et al. (2003) reported higher lysine content in lupin seed than the value of the present study. Other essential amino acids (Histidine, valine, isoleucine, leucine and phenylalanine plus tyrosine) are comparable to the reference protein (FAO/WHO, 1991). Non-essential amino acids such as serine, glycine, alanine, and proline are found to be 0.50 , $0.76,1.31$ and $1.43 \mathrm{mg} / 100 \mathrm{gm}$ protein, respectively. The amino acids composition was changed with varied patterns during processing. Boiling of lupin seeds and debittering increased the level of most amino acids. Germinated and fermented seeds before and after boiling had a variable impact on amino acids composition but most of the amino acids content was increased especially after boiling of the treated seeds. Mubarak (2005) reported a decrease in some essential amino acids after germination of mung bean seeds for 3 days. Transamination and deamination reactions that may occur during fermentation could be responsible for the changes observed in the amino acids profile of the seeds. Boiling in water had been reported to increase the essential amino acids in some legume seeds (Khattab et al., 2009). Yorgancilar and Bilgiçli (2014) declared that bulgur processing of bitter and sweet lupin seeds (Lupinus albus L.) caused a significant increase $(\mathrm{P} \leq 0.05)$ in protein and amino acid content. The results obtained showed that processing of lupin seeds improved the level of some amino acids such as lysine.

Table 2 Effect of different processing methods on amino acids content (mg $\left.100 \mathrm{~g}^{-1} \mathrm{DM}\right) *$ of lupin seeds

\begin{tabular}{|c|c|c|c|c|c|c|c|c|c|c|c|}
\hline \multirow{3}{*}{ Amino acid } & \multirow{2}{*}{\multicolumn{2}{|c|}{ Lupin seeds }} & \multicolumn{6}{|c|}{ Germination time (days) } & \multirow{2}{*}{\multicolumn{2}{|c|}{ Fermented seeds }} & \multirow{3}{*}{ DS } \\
\hline & & & \multicolumn{2}{|c|}{2} & \multicolumn{2}{|c|}{4} & \multicolumn{2}{|c|}{6} & & & \\
\hline & Raw & Boiled & Raw & Boiled & Raw & Boiled & Raw & Boiled & Raw & Boiled & \\
\hline \multicolumn{12}{|c|}{ Essential amino acids (EAA): } \\
\hline \multirow{2}{*}{ Threonine } & 0.83 & 1.23 & 1.07 & 1.27 & 0.78 & 1.20 & 0.82 & 1.20 & 1.03 & 1.30 & 0.98 \\
\hline & $\pm 0.02^{\mathrm{b}}$ & $\pm 0.53^{\mathrm{a}}$ & $\pm 0.06^{\mathrm{a}}$ & $\pm 0.05^{\mathrm{a}}$ & $\pm 0.07^{\mathrm{b}}$ & $\pm 0.02^{\mathrm{a}}$ & $\pm 0.01^{\mathrm{b}}$ & $\pm 0.12^{\mathrm{a}}$ & $\pm 0.03^{\mathrm{a}}$ & $\pm 0.04^{\mathrm{a}}$ & $\pm 0.02^{\mathrm{b}}$ \\
\hline \multirow[b]{2}{*}{ Cystine } & 0.22 & 0.22 & 0.22 & 0.32 & 0.25 & 0.22 & 0.26 & 0.25 & 0.40 & 0.46 & 0.24 \\
\hline & $\pm 0.02^{\mathrm{c}}$ & $\pm 0.02^{\mathrm{c}}$ & $\pm 0.02^{\mathrm{c}}$ & $\pm 0.04^{\mathrm{b}}$ & $\pm 0.09^{\mathrm{bc}}$ & $\pm 0.03^{\mathrm{d}}$ & $\pm 0.09^{\mathrm{b}}$ & $\pm 0.05^{\mathrm{c}}$ & $\pm 0.04^{\mathrm{a}}$ & $\pm 0.02^{\mathrm{a}}$ & $\pm 0.01^{\mathrm{c}}$ \\
\hline \multirow[b]{2}{*}{ Valine } & 1.41 & 1.72 & 1.58 & 1.64 & 1.47 & 1.77 & 1.53 & 1.82 & 1.76 & 2.00 & 1.64 \\
\hline & $\pm 0.08^{\mathrm{c}}$ & $\pm 0.16^{\mathrm{a}}$ & $\pm 0.12^{\mathrm{b}}$ & $\pm 0.14^{\mathrm{b}}$ & $\pm 0.22^{\mathrm{c}}$ & $\pm 0.21^{\mathrm{a}}$ & $\pm 0.22^{\mathrm{c}}$ & $\pm 0.13^{\mathrm{b}}$ & $\pm 0.21^{\mathrm{a}}$ & $\pm 0.12^{\mathrm{a}}$ & $\pm 0.02^{\mathrm{b}}$ \\
\hline \multirow{2}{*}{ Methionine } & 0.08 & 0.09 & 0.06 & 0.07 & 0.06 & 0.05 & 0.03 & 0.05 & 0.09 & 0.07 & 0.03 \\
\hline & $\pm 0.01^{\mathrm{ab}}$ & $\pm 0.02^{\mathrm{ab}}$ & $\pm 0.01^{\mathrm{bc}}$ & $\pm 0.02^{\mathrm{b}}$ & $\pm 0.01^{\mathrm{bc}}$ & $\pm 0.01^{\mathrm{bc}}$ & $\pm 0.004^{\mathrm{d}}$ & $\pm 0.01^{\mathrm{bc}}$ & $\pm 0.01^{\mathrm{a}}$ & $\pm 0.01^{\mathrm{a}}$ & $\pm 0.005^{\mathrm{b}}$ \\
\hline \multirow{2}{*}{ Isoleucine } & 1.57 & 1.74 & 1.57 & 1.83 & 1.52 & 1.82 & 1.53 & 1.70 & 1.98 & 2.00 & 1.68 \\
\hline & $\pm 0.26^{\mathrm{c}}$ & $\pm 0.32^{\mathrm{a}}$ & $\pm 0.32^{\mathrm{b}}$ & $\pm 0.13^{\mathrm{a}}$ & $\pm 0.17^{\mathrm{b}}$ & $\pm 0.31^{\mathrm{a}}$ & $\pm 0.05^{\mathrm{b}}$ & $\pm 0.23^{\mathrm{a}}$ & $\pm 0.17^{\mathrm{a}}$ & $\pm 0.27^{\mathrm{a}}$ & $\pm 0.03^{\mathrm{b}}$ \\
\hline \multirow{2}{*}{ Leucine } & 2.15 & 2.36 & 2.27 & 2.56 & 2.09 & 2.57 & 2.08 & 2.43 & 2.64 & 2.73 & 2.31 \\
\hline & $\pm 0.11^{\mathrm{b}}$ & $\pm 0.21^{\mathrm{a}}$ & $\pm 0.02^{\mathrm{a}}$ & $\pm 0.22^{\mathrm{a}}$ & $\pm 0.03^{\mathrm{a}}$ & $\pm 0.16^{\mathrm{a}}$ & $\pm 0.23^{\mathrm{a}}$ & $\pm 0.15^{\mathrm{a}}$ & $\pm 0.11^{\mathrm{a}}$ & $\pm 0.42^{\mathrm{a}}$ & $\pm 0.03^{\mathrm{b}}$ \\
\hline \multirow{2}{*}{ Tyrosine } & 0.73 & 0.79 & 0.87 & 0.97 & 0.67 & 0.92 & 0.72 & 0.89 & 1.13 & 1.21 & 0.98 \\
\hline & $\pm 0.01^{\mathrm{c}}$ & $\pm 0.21^{\mathrm{c}}$ & $\pm 0.21^{\mathrm{b}}$ & $\pm 0.22^{\mathrm{b}}$ & $\pm 0.02^{\mathrm{c}}$ & $\pm 0.12^{\mathrm{b}}$ & $\pm 0.06^{\mathrm{c}}$ & $\pm 0.04^{\mathrm{c}}$ & $\pm 0.07^{\mathrm{a}}$ & $\pm 0.02^{\mathrm{a}}$ & $\pm 0.02^{\mathrm{b}}$ \\
\hline \multirow{2}{*}{ Phenylalanine } & 1.11 & 1.21 & 1.17 & 1.51 & 1.03 & 1.18 & 1.16 & 1.46 & 1.54 & 1.60 & 1.30 \\
\hline & $\pm 0.06^{\mathrm{b}}$ & $\pm 0.13^{\mathrm{b}}$ & $\pm 0.11^{\mathrm{b}}$ & $\pm 0.21^{\mathrm{a}}$ & $\pm 0.13^{\mathrm{b}}$ & $\pm 0.22^{\mathrm{b}}$ & $\pm 0.32^{\mathrm{b}}$ & $\pm 0.51^{\mathrm{a}}$ & $\pm 0.15^{\mathrm{a}}$ & $\pm 0.21^{\mathrm{a}}$ & $\pm 0.04^{\mathrm{a}}$ \\
\hline \multirow{2}{*}{ Histidine } & 0.61 & 0.80 & 0.75 & 0.86 & 0.62 & 0.78 & 0.67 & 0.78 & 0.81 & 0.89 & 0.66 \\
\hline & $\pm 0.0^{\mathrm{b}}$ & $\pm 0.13^{\mathrm{a}}$ & $\pm 0.02^{\mathrm{a}}$ & $\pm 0.04^{\mathrm{a}}$ & $\pm 0.05^{\mathrm{b}}$ & $\pm 0.03^{\mathrm{a}}$ & $\pm 0.01^{\mathrm{b}}$ & $\pm 0.09^{\mathrm{a}}$ & $\pm 0.01^{\mathrm{a}}$ & $\pm 0.07^{\mathrm{a}}$ & $\pm 0.01^{\mathrm{b}}$ \\
\hline \multirow{2}{*}{ Lysine } & 1.14 & 1.41 & 1.50 & 1.78 & 1.18 & 1.70 & 1.22 & 1.58 & 1.51 & 1.87 & 1.29 \\
\hline & $\pm 0.06^{\mathrm{d}}$ & $\pm 0.14^{\mathrm{b}}$ & $\pm 0.12^{\mathrm{b}}$ & $\pm 0.22^{\mathrm{a}}$ & $\pm 0.17^{\mathrm{d}}$ & $\pm 0.14^{\mathrm{a}}$ & $\pm 0.24^{\mathrm{c}}$ & $\pm 0.33^{\mathrm{b}}$ & $\pm 0.42^{\mathrm{b}}$ & $\pm 0.27^{\mathrm{a}}$ & $\pm 0.02^{\mathrm{c}}$ \\
\hline \multicolumn{12}{|c|}{ Non-essential amino acids (NEAA): } \\
\hline \multirow{2}{*}{ Arginine } & 2.99 & 3.16 & 3.37 & 3.85 & 2.92 & 3.42 & 2.88 & 2.87 & 3.67 & 4.37 & 3.27 \\
\hline & $\pm 0.27^{\mathrm{c}}$ & $\pm 0.42^{\mathrm{b}}$ & $\pm 0.30^{\mathrm{b}}$ & $\pm 0.09^{\mathrm{b}}$ & $\pm 0.31^{\mathrm{c}}$ & $\pm 0.23^{\mathrm{b}}$ & $\pm 0.12^{\mathrm{c}}$ & $\pm 0.24^{\mathrm{c}}$ & $\pm 0.53^{\mathrm{b}}$ & $\pm 0.44^{\mathrm{a}}$ & $\pm 0.05^{\mathrm{b}}$ \\
\hline \multirow{2}{*}{ Proline } & 1.43 & 1.61 & 1.39 & 1.84 & 1.65 & 1.65 & 1.79 & 1.69 & 1.95 & 1.90 & 1.83 \\
\hline & $\pm 0.09^{\mathrm{c}}$ & $\pm 0.14^{\mathrm{b}}$ & $\pm 0.13^{\mathrm{c}}$ & $\pm 0.31^{\mathrm{a}}$ & $\pm 0.23^{\mathrm{b}}$ & $\pm 0.11^{\mathrm{b}}$ & $\pm 0.32^{\mathrm{b}}$ & $\pm 0.21^{\mathrm{b}}$ & $\pm 0.13^{\mathrm{a}}$ & $\pm 0.50^{\mathrm{a}}$ & $\pm 0.23^{\mathrm{a}}$ \\
\hline \multirow{2}{*}{ Aspartic acid } & 2.08 & 2.98 & 3.40 & 3.52 & 2.86 & 4.01 & 3.63 & 4.74 & 2.55 & 3.69 & 2.26 \\
\hline & $\pm 0.07^{\mathrm{c}}$ & $\pm 0.16^{\mathrm{c}}$ & $\pm 0.11^{\mathrm{b}}$ & $\pm 0.13^{\mathrm{b}}$ & $\pm 0.09^{\mathrm{c}}$ & $\pm 0.08^{\mathrm{a}}$ & $\pm 0.41^{\mathrm{b}}$ & $\pm 0.32^{\mathrm{a}}$ & $\pm 0.02^{\mathrm{c}}$ & $\pm 0.02^{\mathrm{b}}$ & $\pm 0.08^{\mathrm{c}}$ \\
\hline & 0.50 & 0.64 & 1.32 & 1.03 & 0.65 & 1.52 & 0.66 & 1.50 & 0.68 & 1.36 & 0.73 \\
\hline Serine & $\pm 0.08^{\mathrm{d}}$ & $\pm 0.11^{\mathrm{d}}$ & $\pm 0.2^{\mathrm{b}}$ & $\pm 0.13^{\mathrm{b}}$ & $\pm 0.08^{\mathrm{cd}}$ & $\pm 0.21^{\mathrm{a}}$ & $\pm 0.09^{\mathrm{cd}}$ & $\pm 0.23^{\mathrm{a}}$ & $\pm 0.02^{\mathrm{c}}$ & $\pm 0.14^{\mathrm{b}}$ & $\pm 0.04^{\mathrm{c}}$ \\
\hline & 4.64 & 5.24 & 7.10 & 8.33 & 3.63 & 7.85 & 3.49 & 6.99 & 5.52 & 7.99 & 3.99 \\
\hline Glutamıc acid & $\pm 0.31^{\mathrm{c}}$ & $\pm 0.40^{\mathrm{c}}$ & $\pm 0.08^{\mathrm{b}}$ & $\pm 0.12^{\mathrm{a}}$ & $\pm 0.02^{\mathrm{d}}$ & $\pm 0.24^{\mathrm{a}}$ & $\pm 0.21^{\mathrm{d}}$ & $\pm 0.18^{\mathrm{b}}$ & $\pm 0.03^{\mathrm{c}}$ & $\pm 0.10^{\mathrm{a}}$ & $\pm 0.12^{\mathrm{c}}$ \\
\hline Slycine & 0.76 & 0.87 & 1.31 & 1.44 & 0.76 & 1.40 & 0.79 & 1.35 & 1.14 & 1.45 & 0.88 \\
\hline Glycine & $\pm 0.04^{\mathrm{e}}$ & $\pm 0.10^{\mathrm{e}}$ & $\pm 0.12^{\mathrm{a}}$ & $\pm 0.23^{\mathrm{ab}}$ & $\pm 0.04^{\mathrm{e}}$ & $\pm 0.02^{\mathrm{b}}$ & $\pm 0.03^{\mathrm{e}}$ & $\pm 0.31^{\mathrm{c}}$ & $\pm 0.22^{\mathrm{d}}$ & $\pm 0.14^{\mathrm{a}}$ & $\pm 0.07^{\mathrm{e}}$ \\
\hline & 1.31 & 1.19 & 1.13 & 1.23 & 1.39 & 1.22 & 1.45 & 1.30 & 1.60 & 1.38 & 1.51 \\
\hline Alanine & $\pm 0.24^{\mathrm{b}}$ & $\pm 0.17^{\mathrm{b}}$ & $\pm 0.22^{\mathrm{d}}$ & $\pm 0.32^{\mathrm{c}}$ & $\pm 0.09^{\mathrm{b}}$ & $\pm 0.02^{\mathrm{c}}$ & $\pm 0.32^{\mathrm{b}}$ & $\pm 0.21^{\mathrm{b}}$ & $\pm 0.13^{\mathrm{a}}$ & $\pm 0.11^{\mathrm{b}}$ & $\pm 0.04^{\mathrm{a}}$ \\
\hline & 1.81 & 1.90 & 1.94 & 1.88 & 1.80 & 2.00 & 2.05 & 2.08 & 1.73 & 2.08 & 1.78 \\
\hline Ammonia & $\pm 0.33^{\mathrm{d}}$ & $\pm 0.21^{\mathrm{d}}$ & $\pm 0.37^{\mathrm{c}}$ & $\pm 0.43^{\mathrm{cd}}$ & $\pm 0.41^{\mathrm{d}}$ & $\pm 0.11^{\mathrm{bc}}$ & $\pm 0.15^{\mathrm{b}}$ & $\pm 0.14^{\mathrm{b}}$ & $\pm 0.17^{\mathrm{e}}$ & $\pm 0.12^{\mathrm{b}}$ & $\pm 0.09^{\mathrm{d}}$ \\
\hline
\end{tabular}




\section{Conclusion}

In conclusion, the present study revealed that Golo cultivar had a considerable amount of protein and EAA. The seeds contained an appreciable amount of antinutritional factors (tannin and phytate). However, processing of the seeds alleviate the effect of such factors and improve the protein quality.

\section{References}

Ahmed S B, Mahgoub SA, Babiker, E E. 1996. Changes in tannin and cyanide contents and diastatic activity during germination and the effect of traditional processing on cyanide content of sorghum cultivars. Food Chemistry, 56: 159-162.

AOAC 1990. Association of Official Analytical Chemists. Official Methods of Analysis, $15^{\text {th }}$ edn., Washington DC.

Chilomer K, Zaleska K, Ciesiolka D, Gulewicz P, Frankiewicz A, Gulewicz K. 2010. Changes in the alkaloids, $\alpha$-galactoside and protein fraction content during germination of different lupin species. Acta Societatis Botanicorum Poloniae, 79: 11-20.

Desphande SS, Salunkhe UK, Oyewole OB, Azarn-Ali S, Battcock M, Bressani R. 2000. Fermented grain legumes: seeds and nuts. A global perspective. FAO Agric. Services Bulletin, 142, Rome, Italy, pp. 1-53.

Duranti M, Gorinstein S., Cerletti P. 1990. Synthesis of storage proteins and seed development in L. albus under different growth conditions. Journal of Food Biochemistry, 14: 327-330.

El-Adawy TA, Rahma EH, El-Bedawey AA, Gafar AF. 2001. Nutritional potential and functional properties of sweet and bitter lupin seed protein isolates. Food Chemistry, 74(4): $455-$ 462.

ElMaki HB, AbdelRahaman SM, Idris WH, Hassan AB, Babiker EE, ElTinay AH. 2007. Content of antinutritional factors and $\mathrm{HCl}$-extractability of minerals from white bean (Phaseolus vulgaris) cultivars: Influence of soaking and/or cooking. Food Chemistry, 100: 362-368.

FAO/WHO. 1991. Protein quality evaluation. Report of a joint FAO-WHO expert consultation. Rome, FAO, Food and Nutrition, 51.

Frías J, Vidal-Valverde C, Sotomayor C, Diaz-pollan C, Urbano G. 2000. Influence of processing on available carbohydrate content and antinutritional factors of chickpea. Zeitschrift fur lebens mittel untersuchung and forschung, 210: 340-345.

Gulewicz P, Martínez-Villaluenga C, Frias J, Gulewicz DCK, Vidal-Valverde C. 2008. Effect of germination on the protein fraction composition of different lupin seeds. Food Chemistry, 107: 830-844.

Ibrahim SS, Habiba RA, Shatta AA, Embaby HE. 2002. Effect of soaking, germination, cooking and fermentation on antinutritional factors in cowpeas. Nahrung, 46: 92-95.

Idris W H, Samia MA, Hagir B E, Babiker EE, Abdullahi HE. 2007. Effect of malt pretreatment on $\mathrm{HCl}$-extractability of calcium, phosphorus and iron of sorghum (sorghum biocolor) cultivars. International Journal of Food Science and Technology, 42: 194 199.

James LF, Panter KE, Gaffield W, Molyneux RJ. 2004. Biomedical applications of poisonous plant research. Journal of Agricultural and Food Chemistry, 52: 3211-3230.

Khattab RY, Arntfield SD, Nyachoti CM. 2009. Nutritional quality of legume seeds as affected by some physical treatments, Part 1: Protein quality evaluation. LWT-Food Science and Technology, 42: 1107-1112.

Kim DC, Chae HJ, In MJ. 2004. Existence of stable fibrin-clotting inhibitor in salt fermented anchovy sauce. Journal of Food Composition Analysis, 17: 113-118.

KohaJdoVá Z, Karovicova J, Schmidt S. 2011. Lupin composition and possible use in bakery-a review. Czech J Food Sci, 29(3): 203-11.
Kuo Y-H, Rozan P, Lambein F, Frias J, Vidal-Valverde C. 2004. Effects of different germination conditions on the contents of free protein and non-protein amino acids of commercial legumes. Food Chemistry, 86: 537-545.

Lampart-Szczapa E, Siger A, Trojanowska K, Nogala-Kałucka M, Małecka M, Pachołek, B. 2003. Chemical composition and antibacterial activities of lupin seed extracts. Nahrung, 47: 286290.

Landry J, Moureaux T. 1970. Heterogeneity of the glutelins of grain of corn: Selective extraction and composition in amino acid of the three isolated fractions. Bulletin de la Societe nde Chimie Biologique, 52: 1021-1037.

Lone Blanner J, Flengmark P, Gyiling M, ltenov K. 2003. Lupin seed (Lupinus albus and Lupinus luteus) as a protein source for fermentation use. Industrial Crops and Products, 18: 199-211.

Mandal S, Mandal RK. 2000. Seed storage proteins and approaches for improvement of their nutritional quality by genetic engineering. Current Science, 79: 576-589.

Martınez-Villaluenga C, Urbano G, Porres J, Frias J, VidalValverde C. 2007. Improvement in food intake and nutritive utilization of protein from $L$. albus var. multolupa protein isolates supplemented with ascorbic acid. Food Chemistry, 103: 944-951

Mohamed Nour AA, Mohamed Ahmed I A, Babiker EE, Abu ElGasim AY. 2010. Investigations on winter season Sudanese sorghum cultivars: effect of sprouting on the nutritional value. International Journal of Food Science and Technology, 45: 884890.

Mohiedeen IE, Abdullahi HE, Abd Elmoneim OE, Babiker EE, Mallasy LO. 2010. Effect of fermentation and cooking on protein quality of maize (Zea Mays Linnaus) cultivars. International Journal of Food Science \& Technology, 45: 12841290

Monjula S, John E. 1991. Biochemical changes and in vitro protein digestibility of the endosperm of germinating Dolichos lablab. Journal of the Science of Food and Agriculture, 55: 229-238.

Mubarak AE. 2005. Nutritional composition and antinutritional factors of mung bean seeds (Phaseolus aureus) as affected by some home traditional processes. Food Chemistry, 89: 489-495.

Onyango C, Noetzold H, Bley T, Henle T. 2004. Proximate composition and digestibility of fermented and extruded uji from maize-finger millet blend. LWT-Food Science and Technology, 37: 827-832.

Osman NM, Mohamed Ahmed IA, Babiker EE. 2010. Fermentation and cooking of Sicklepod (Cassia obtusifolia) leaves: Changes in chemical and amino acid composition, antinutrients and protein fractions and digestibility. International Journal of Food Science and Technology, 45: 124-132.

Price ML, Van Scoyoc S, Butler LG. 1978. A critical evaluation of the vanillin reactions as an assay for tannin in sorghum grain. Journal of Agricultural and Food Chemistry, 26: 1214-1218.

Snedecor GW, Cochran WG. 1987. Statistical Methods, $17^{\text {th }}$ edn. Pp. 221-222. Ames, 1A: The Iowa State University Press.

Sokrab AM, Mohamed Ahmed IA, Babiker EE. 2012. Effect of malting and fermentation on antinutrients, and total and extractable minerals of high and low phytate corn genotypes. International Journal of Food Science and Technology, 47: 1037-1043.

Sulieman MA, Mohamed AM, Elhadi AI, Babiker EE, Abdullahi HE. 2007. Changes in Chemical Composition, Phytate, Phytase Activity and Minerals Extractability of Sprouted Lentil Cultivars. Journal of Biological Sciences, 7: 776-780.

Urbano G, Aranda P, Vilchez A, Aranda C, Cabrera L, Porres J. 2005. Effects of germination on the composition and nutritive value of proteins in Pisum sativum L. Food Chemistry, 93: 671-679.

Wheeler EL, Ferrel RE. 1971. A method for phytic acid determination in wheat and wheat fractions. Cereal Chemistry, 28: $313-320$

Wong AHK, Mine Y. 2004. Novel fibrinolytic enzyme in fermented shrimp paste, a traditional Asian fermented seasoning. Journal of Agricultural and Food Chemistry, 52: 980-986. 
Yagoub AA, Mohamed EB, Ahmed AHR, El Tinay AH. 2004 Study on fururndu, a Traditional Sudanese fermented roselle (Hibiscus sabdariffa L.) seed: Effect on in vitro protein digestibility, chemical composition and functional properties of the total proteins. Journal of Agricultural and Food Chemistry, 52: 6143- 6150
Yorgancilar M., Bilgiçli N. 2014. Chemical and nutritional changes in bitter and sweet lupin seeds (Lupinus albus $L$.) during bulgur production. Journal of food science and technology, 51:13841389.

Yousif NE, El Tinay AH. 2000. Effect of fermentation on protein fractions and in vitro protein digestibility of maize. Food Chemistry, 70: 181-184. 